\title{
Investigating the Stratigraphy and the Gender of Nano-Fossils in the Lower Part of the Abtalkh Formation in Kopet Dagh Zone
}

\author{
Jafar Ghomi Oyli \\ Islamic Azad University of Chaloos, Chaloos, Iran \\ Email: j.ghomi1388@gmail.com
}

How to cite this paper: Oyli, J.G. (2016) Investigating the Stratigraphy and the Gender of Nano-Fossils in the Lower Part of the Abtalkh Formation in Kopet Dagh Zone. Open Journal of Geology, 6, 1499-1512. http://dx.doi.org/10.4236/ojg.2016.612106

Received: September 29, 2016

Accepted: December 3, 2016

Published: December 6, 2016

Copyright $\odot 2016$ by author and Scientific Research Publishing Inc. This work is licensed under the Creative Commons Attribution International License (CC BY 4.0).

http://creativecommons.org/licenses/by/4.0/

\begin{abstract}
A structural-sediment zone of Kopet Dagh is one of the geological units. The southern Kopet Dagh zone is limited to Binalood and the northern limit is with the Turan plateau fault and is created as sediment (Trough) in the late Triassic. The main fault zones are divided into two groups of foundation faults and overthrust. Kopet Dagh is a giant gas field between Turkmenistan, Iran and Afghanistan. Most areas of the region have a temperate climate so cold. From the middle Cambrian to the present, five phases of orogeny have occurred in the region. The geographic location of the study area is $37^{\circ} 43^{\prime} 03^{\prime \prime} \mathrm{N}$ latitude and $55^{\circ} 35^{\prime} 47^{\prime \prime} \mathrm{E}$. In terms of stratigraphic formations in the Cretaceous period, Kopet Dagh area, respectively, is from old to new, including: Shurijeh, Zard, Tiregan, Sar Cheshmeh, Sanganeh, Aitamir, Abderaz, Abtalkh, Neyzar and Kalat. Abtalkh formation is one of the most important rock units in the late Cretaceous in the Kopet Dagh Basin. Abtalkh formation is $489 \mathrm{~m}$ and its stratigraphic units are 80 meters of dark grayshale, $20 \mathrm{~km}$ dark grayshale with calcareous layers with Inoseramus, $50 \mathrm{~m}$ gray marl tend to bluish with Siliceous limestone interlayers, 19 meters of gray-blueshale, 320 meters of light gray shale withthinlayer limestone interlayers. To take pictures of the samples, $100 \times$ objective lens and digital camera were used. In the course of this study, the lower part of Abtalkh formation was in Itamir cutting of the study and 9 genera were identified. Recognized calcareous Nannofossil had diversity and abundance. In general, in the greater thickness of the study, samples have moderate preservation. In some cases, the impact of dissolution phenomenon was so great that the main part of the species were corroded. Paying attention to the range of the rise and fall of index species and fossil assemblages, 4 biozones were identified for cutting according to the zones (CC18-CC21) of Sysyngzoning, 1977.
\end{abstract}

\section{Keywords}

Structural Zone of Kopet Dagh, Calcareous Nannofossil, Abtalkh Formation, 
Stratigraphic

\section{Introduction}

Sedimentary-structural Kopet Dagh is one of the geological units. South limit of Kopet Dagh is limited to Binalood and the northern limit is the plateau Turan fault. Kopet Dagh is a mountainous region that has become the current landscape, because of the latest phase of Alpine folding and erosion of its outcome. The Kopet Dagh zone becomes sediment basin after the early Cimmerian orogeny, meaning when apparently a collision between Iran and Turan was ended [1]. The basin is created by the closure of the Paleo-Tethys Ocean and during the Middle to Late Triassic orogenic and probably in the Middle Jurassic. It is composed of two thick carbonate and debris sediments that were deposited from the Jurassic to the Neogene.

Kopet Dagh is a large gas field among the three countries of Iran, Afghanistan and Turkmenistan and huge gas fields of Khangiran in Iran, Dolat Abad-Donmez, Sharlik, Gazelle, Bayran Ali and Mehri in Turkmenistan and Sulfur in Afghanistan have been discovered in the basin. Basin area is about 5500 square kilometers and is approximately $3.3 \%$ of the total area of Iran (Figure 1). Two parallel mountain ranges cover the most surface area. North ranges are Kopet Dagh Mountains and thousands of mosques and southern ranges are Golestan, Aladagh and Binalood Mountain. Most sedimentary rocks of Mesozoicand Tertiary cover Kopet Dagh. The thickness of sedimentary rocks

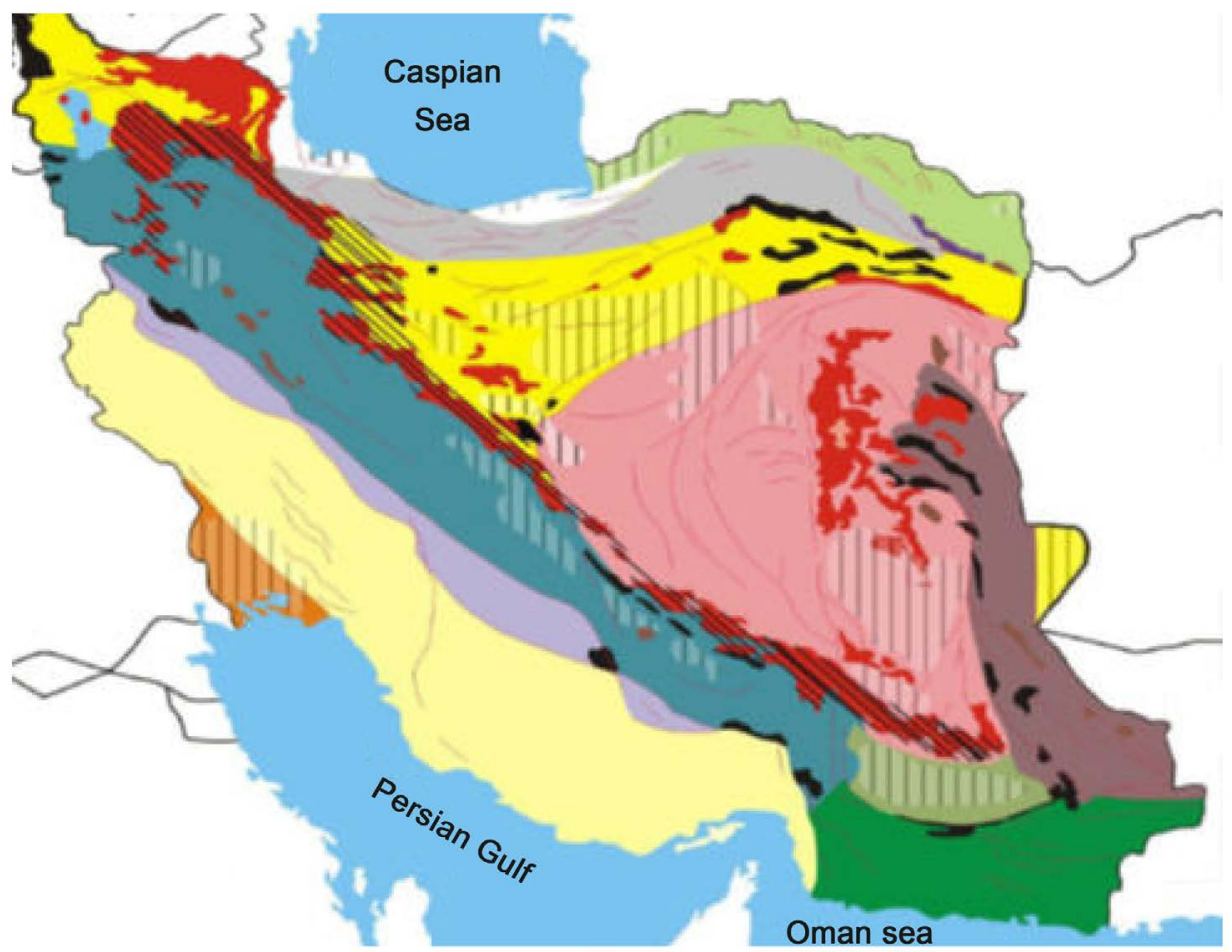

Figure 1. Position Kopet Dagh Basin (Nezafati, 2006). 
in some areas is over eight thousand meters. Precipitation of tectonic events, governing the Kopet Dagh zone is similar to the Zagros zone, such that it can be referred to final folding, public process of folds, lack of magmatic endeavors, and the same regimen for compression and so on. Kopet Dagh region's weather is influenced by several factors. One of these factors can be the change in the country districts that changes at a height of 28 meters below sea level to over 3000 meters above sea level. Most areas of the region have cold temperate climate. Of course, parts such as Sarakhs and Jajarm parts have a desert climate and some areas such as the southern part of Gorgan have a Mediterranean climate. The general trend of winds is in north south, but seasonal winds are blowing with east west trending in summer and west-east in winter. There are two different views about the place of Kopet Dagh zone: A) Eurasian theory in the Aq Darband Lias deposits with a clear unconformity is on the row of pyroclastic deposits with complex construction and with the Middle-Late Triassic. They know the Kopet Dagh as a part of the Eurasian continent and ultramafic rocks of Mashhad area, the remnants of an ocean. This group of geologists knows the Kopet Dagh as a part of the Eurasian continent and ultramafic rocks of the Mashhad area as the remnants of the ocean that separate two Turan (Eurasia) and Iran (Gondwana) plates from each other and has continued to the East, along the Heart fault to the Hindu Kush. B) [2] knows late-Precambrian Paleozoic rocks of Ghare bil area as the same ore deposits at the same time, in central Iran and East Alborz and believes that the Epica Tangayy platform of Paleozoic Iran are over or part of Kopet Dagh mountains. A folding model of Kopet Dagh, compared with the Zagros has been compared. According to the cases, such as high intensity of folding on the southern side, asymmetric, and steepened the southwest of the folds, it seems that the Iranian plate movement to the Kopet Dagh has a major role in the precipitate folding. Such a move has caused a mechanism change of foundation rock faults from normal to drift, with the slope to the north, and the calving strike-slip faults that matches in the direction of fault couples along the compression in the Kopet Dagh fold belt. From the middle Cambrian to the present, there are five phases of orogeny in the region. 1) The beginning Kimerin orogenic that place the Kashafrud formation with age Bajocian-in the form of unconformably on late Triassic rocks in the area Aqdarband. 2) The sub-Hercynian orogeny of Kalat formation that places in the Shlamy syncline in the form of unconformablyon Sanganeh Formation horizon and Aitamir. Expresses the activity of styrene is orogeny. 3) Styrene orogenic, the folds of the upper layers AbTalkh Formation with Late Eocene age, or old oligo age, consistent with older formation and collapse of continental red clastic sediments, on the Khangiran the Oligocene to Miocene age in accordance with Khangiran formation, is representative of styrene orogenic activity. 4) Attica Orogenic of continental clastic rocks redwith late Miocene age in the region, folded and with unconformity on the different older rocks. 5) Pasadenian Orogenic the folding conglomerate with Pliocene age that place unconformably on the Red continental sediments of Miocene and older formations. Drought in an area is the same time with the major phases of the world orogeny. The first drought is at the end of Lower Cambrian and the last drought is the beginning of the 
Eocene age. Foundation and thrust faults are the main faults of the region.

\section{Background of the Research}

Geological research in the Kopet Dagh has done by Grisbakhaz of India geology organization in 1881. Geologists of Amiranin Oil Company did the first systematic studies of geology and operations in the region. This enterprise geologist has studied the East and Northeast of Iran in the years 1938. 1937. From 1938 to 1951, an important geological work has not been done in the area. Ganser, Switzerland, geologist, in 1951, that was employed by the national oil company, for two months of working geological, has recognized the outcrops surrounding Gorgan to Maravetappe meridian, and has prepared the geological maps in the scale of 100,000:1. Goldashmit and Fakhraei in 1952 by the National Iranian Oil Company, for two months field work, from ferns to the Maravetappe meridian with geological maps identifying the scale of 253,440:1. In 1956 Perrin and Jahanbeglo, Iranian oil company geologists' prepared stratigraphic sections in Sarakhs.

[3] has drawn the Geological map of Kopet Dagh. [4] has studied geological exploration of gas fields in Sarakhs and Khangiran. [5] has studied foraminifera in sediment sequence of Kopet Dagh of the Middle Jurassic to Upper Cretaceous. [6] [7] [8] during six months of field work in the area, has performed stratigraphic complementary harvest and Geology, which results are in his doctoral thesis. [9] geological mapping at a scale of 1:250,000 of [10] has drawn the geological map at 1:50,000 scale of the anticline Khangiran in Sarakhs. [11] has studied Mozduran formation depositional environment in East of Kopet Dagh. [12] have studied the geodynamic ophiolite importance in late Paleozoic rocks in the north east of Iran. [13] has studied calcareous Nannoplankton of the sedimentary sequence starting Maastrichtian-Tertiary in Sarakhs region. [14] has studied and examined the calcareous Nannoplankton of North Khorasan.

\section{The General Geology}

Abtalkh Formation is one of the most important Late Cretaceous rock units in the Kopet Dagh Basin (North East Iran). In order to study the formation, a cut was selected and sampled in the west of the Kopet Dagh Basin. The cut is located in $100 \mathrm{~km}$ of Gonbad-e Qabus and $35 \mathrm{~km}$ from the city Maravetappe in the South East of Aitamir village and north of the Cherta village. Geographical coordinates of the cut were the $37^{\circ} 43^{\prime} 03^{\prime \prime} \mathrm{N}$ latitude and $55^{\circ} 35^{\prime} 47^{\prime \prime} \mathrm{E}$ (Figure 2).

\subsection{Stratigraphic}

\subsubsection{Cretaceous Stratigraphy in the Kopet Dagh}

Cretaceous is the longest second period. In general, the Cretaceous period, in terms of the Kernostratigraphy, includes follows dividend: beginning Cretaceous, including Berriasian Eshkobss, Valanzhynyn, Hatrvyn, Barremian, Aptian and Albian. The collection

of Valanzhyn, Hatrvyn and Barremian-, Neocomian and Late Cretaceous include the Cenomanian, Turonian, Senonin (Coniacian, Santonian, Campanian) and Maastrichtian. 


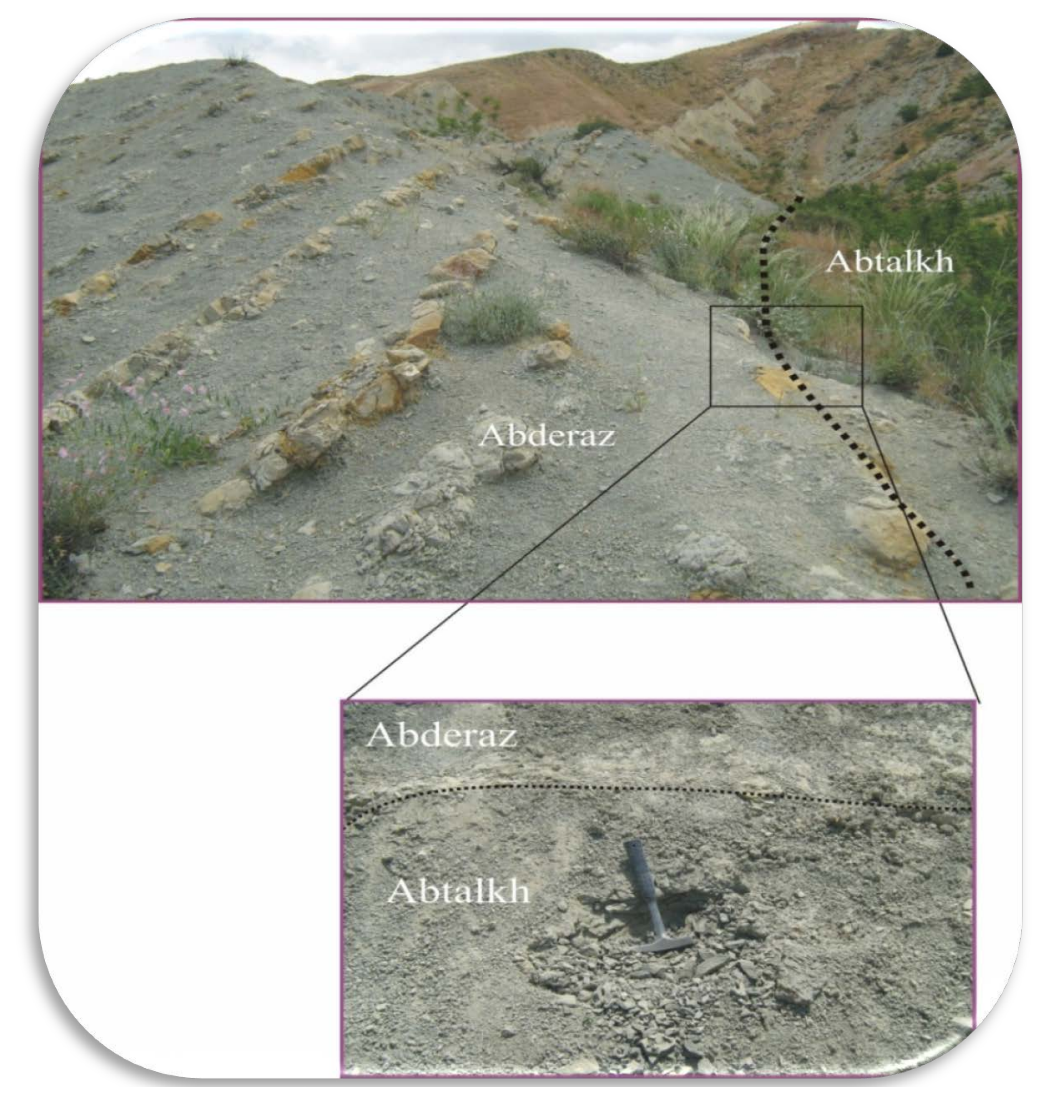

Figure 2. Illustration of Abderaz and Abtalkh formation border in the study section.

Since the late Jurassic, an embayment with approximate east west trending was emerged in the region that was active during the Cretaceous and governed the sedimentation region. The relative movements of blocks related to this embayment have caused facies changes, thickness changes and lack of sediments. In the Kopet Dagh area, sedimentation, between the Jurassic and Cretaceous, had continuous mode, and the most complete Cretaceous sediments are in Iran in this area, particularly in the East. Cretaceous period formations of the Kopet Dagh region, respectively, from old to new area include:

Shurijeh formation: type section of Shurijeh formation is measured $50 \mathrm{~km}$ northeastern of Mashhad in the eastern plunge anticline along the river estuary with a thickness of $980 \mathrm{~m}$. The lithology is most of detrital sediments (shales, clay, sandstone, conglomerate), slightly gypsum rocks and negligible layers of carbonate rocks is negligible.

Zard Formation: the name of this formation is derived from the Zard village located about 65 kilometers West Bojnoord. A model section of the formation is located in the North of Karkhod Mountains; in 7.5 kilometers of the south West of Zard Village and it has a thickness of 280 meters. Its lithology includes sea marl gray to blue and olive green, marine sandstone in gray to yellow to gray buff and small layers of sandy limestone.

Tirgan formation: from Oolitic limestone and clastic organic and partial layers of 
marinelimestone, marl, and calcareous shale have been formed. The name of the formation as being derived from Tirgan village located at $39 \mathrm{~km}$ south East of Daregez Valley. Location of model section of the formation is located at Tirgan Mountains, 5 $\mathrm{km}$ from Tiregan Village west side.

Sarcheshmeh Formation: The name of this formation is derived from the Sarcheshmeh village, located $14 \mathrm{~km}$ from North East of Bojnurd. Sarcheshmeh Formation is composed of two parts, the lower part that is consisted of the grayand dark graymarland the upper partconsist of dark shale formation alternating layers and thin layers of limestone.

Sanganeh Formation: The name of this formation is derived from the Sanganeh village, located $70 \mathrm{~km}$ north East of Mashhad. Location of model section of the formation is located Ashlar anticline south, eastern tip, in $4 \mathrm{~km}$ from North West of Sanganeh Village and it has a thickness of $740 \mathrm{~m}$. Its lithology includes of shale, siltstone, in some areas, there are thin and a little layers of sandstone at the base of the formations.

Aitamir Formation: The name of this formation is derived from the Aitamir village, located in the East of Kopet Dagh, 70 km North East of Gonbad-e Qabus.

This formation is composed of two parts: sandstone, which contains, glauconitic sandstone, and upper shale, which includes shale gray, greenish olive glauconitic shale.

Abderaz Formation: The name of this formation is derived from the Abderaz village, located in the East of Kopet Dagh, northern West of Mozduran Village. The lithology of this formation includes Chaki limestone that has 3 or 4 bands and light gray bluish to gray white color.

Abtalkh formation: The name of this formation is derived from Abtalkh village that is located in $77 \mathrm{~km}$ North East of Mashhad, on the way Bazangan village in the Chahchahe village. The pattern cut location is after Mozduran neck, in East Main Road in Mashhad to Sarakhs. This formation consists of calcareous shale, gray to blue, with slight layers of marl. Bozorg Nia sen has introduced this formation in the model section based on foraminifera, Santonian-Campanian and Maastrichtian. Hadavi did study on calcareous Nannofossil in Abtalkh, in the West of Chahchahe Village in 2001 and the age of this formation is introduced Late Campanian/Maastrichtian.

Neyzar Formation: The name of this formation is derived from the Tang Neyzar in 14 $\mathrm{km}$ north of Mozduran village and $62 \mathrm{~km}$ South West of Sarakhs. This formation consists of thick layer glauconites and stone and shale with a layer of sand limestone in the upper section.

Kalat Formation: The name of this formation is derived from Kalat Syncline. The limestone of this formation in vertical wall has turned it into a natural fortress that only has a way of entrance from entering and exitingpath of Kalat River. The model cut was introduced in the Tang Neyzar region. Kalat formation consists of sandy limestone, and reef and degradation organic.

\subsubsection{Abtalkh Formation Stratigraphy in Aitamir Cutting (West Basin of Kopet Dagh)}

Abtalkh only outcrop is in the West of the Kopet Dagh basin in Aitamir Syncline. The 
studied section is located in the south flank of the Aitamir syncline that the syncline is located in the north part of Maraveh fault and the East of Aitamir Village. Abtalkh formation in Aitamir syncline is 675 meters calcareous shale and marl in the gray-blue color that the lower and upper boundaries have the same slope and harmonic with Abderaz Formation and the upper limestone unit (as it is called Chehel Kaman). [15] has attributed the passing through silty shales of Abtalkh formation to a thick limestone layer of the upper surface layer continuous and gradual and the limestone rock unit to Kalat formation. Abtalkh formation in the West Basin (Aitamir cutting) has dark bluish gray shale lithology with Inosramus limestone interlayers and Silica limestone interlayers.

On the Cutting,the Abtalkh formation has $489 \mathrm{~m}$ thickness and stratigraphic units are as follows in Figure 3:

-80 meters of dark gray shale.

-20 meters of dark gray shale with Inosramus limestone interlayers.

-50 meters of gray to bluish marl with siliceous limestone interlayers.

-19 meters gray-blue shale.

320 meters of light grey shale with thin layer limestone interlayers.

\section{Results}

\subsection{Microfossils Biozonation}

In this classification, a number of microfossils is expressed. Based on studies in the studied section, 9 genera were identified and photographed. The form of any fossils is at the beginning of each gender and it is then explained.

Plate 1: This Coccolith is an elliptical shape that its proximal bumper consists of two rows of calcite. Its central region lacks a certain buildings and can be seen clearly during
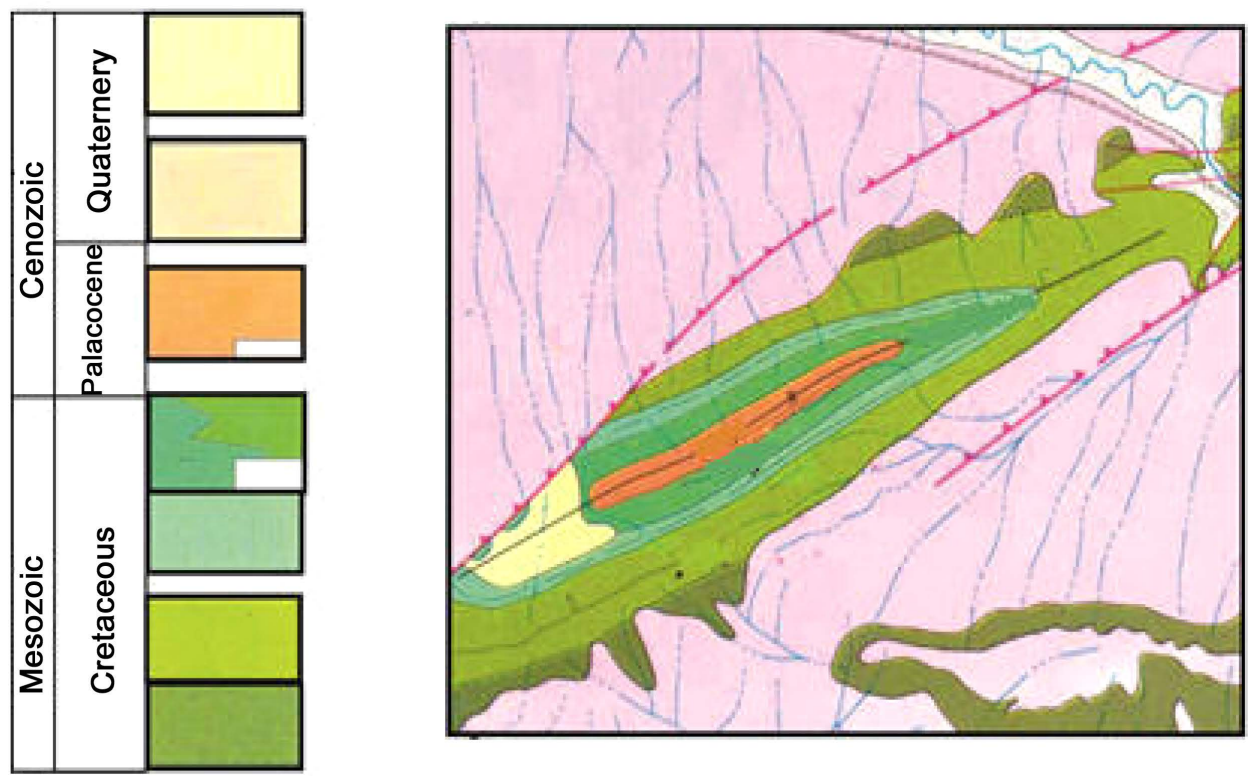

Figure 3. Location cutting Aitamir in geological map of Mount Korkhud [16]. 
studies with the parallel light.

Its age range is Oxfordan-Maastrichtian. These sediments of late Cretaceous have been reported in southern Spain Tunisia and the Paris Basin [18].

Plate 2: This type of Coccolith has anelliptical shape and its distal bumper consists of ring calcite elements that have overlap. They can be seen in bright natural light and two pores in its central region are visible. Its age range is Middle Jurassic-Late Cretaceous.

Plate 3: This type of Coccolith is cube-shaped that is consisted two layers and four blocks of calcite. Four blocks are notconnected and the block ends are sharpened. Seam lines in the central regionare + Age range is Santonian-Maastrichtian.

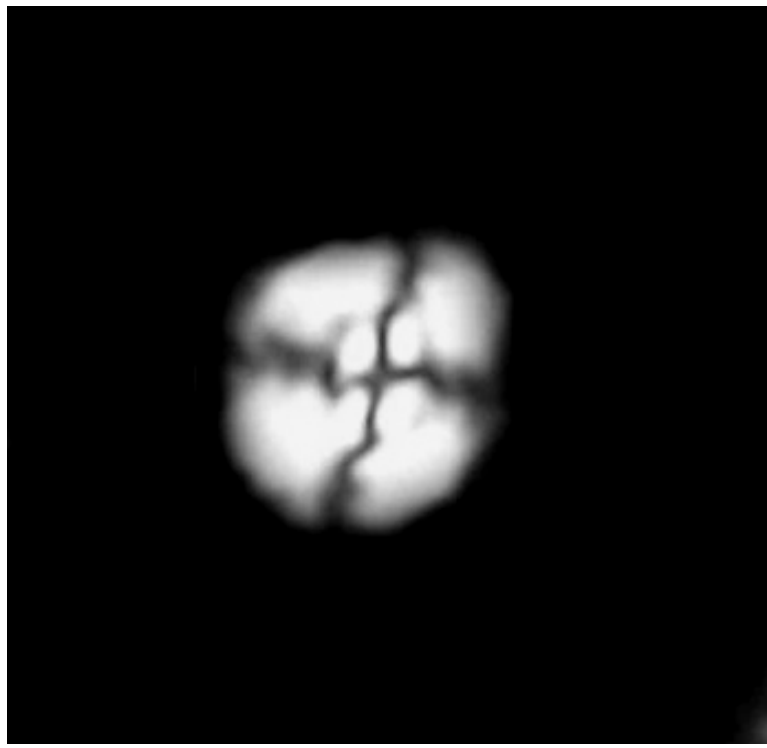

Plate 1. Watznaueria barnesae [17].

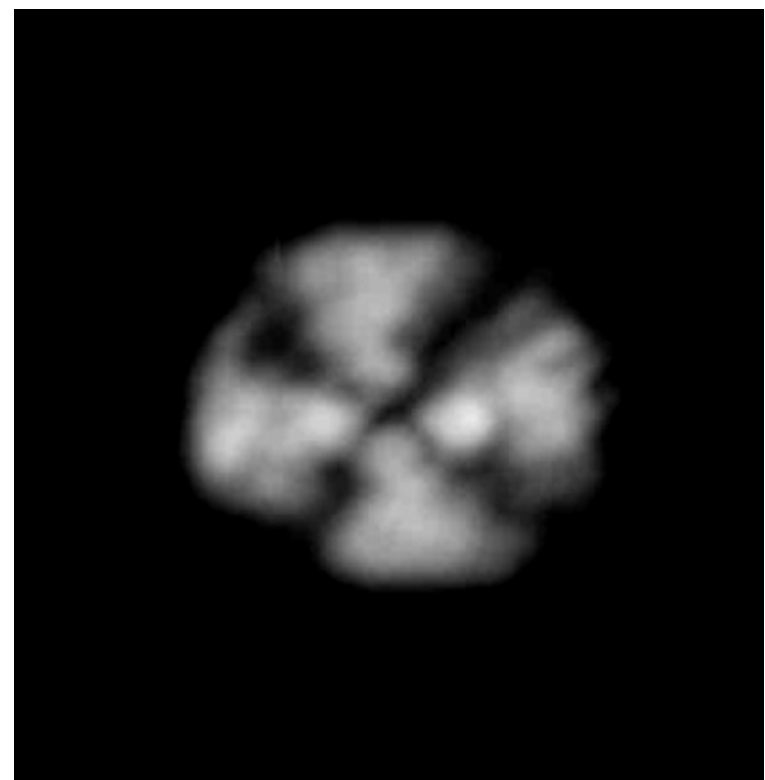

Plate 2. Watznaueria biporta [19]. 
Plate 4: This type of Coccolith is cube-shaped which is composed of four calcite blocks conjoined together. Seam lines are in the central region of the curve. Suture lines in the central region are $\mathrm{X}$ form. The presence of this species is as an indicator of zoning [22]. Age range is Coniacian-Maastrichtian.

Plate 5: This type of Coccolith is cube-shaped that has concavity sides and corners are having protrusion like the horns, in some species, a small central region is visible. The central region has X seam lines. Age range is Santonian-Maastrichtian.

Plate 6: This species is used as an indicator of Zuni in the late Campanian. The Coccolith is composed of three arms. In polarized XPL light, one arm is brighter than the

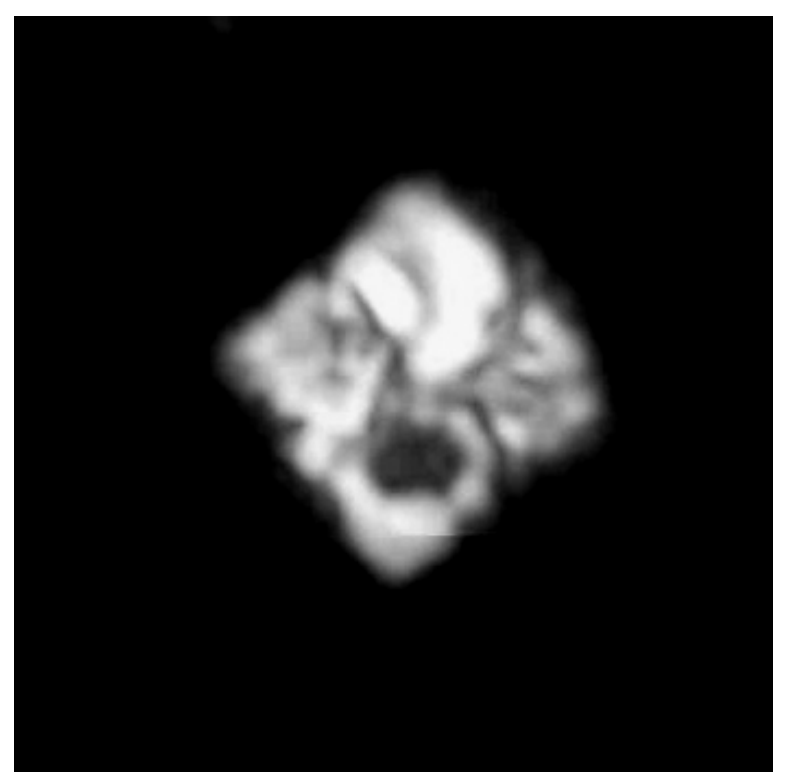

Plate 3. Quadrum gothicum [20].

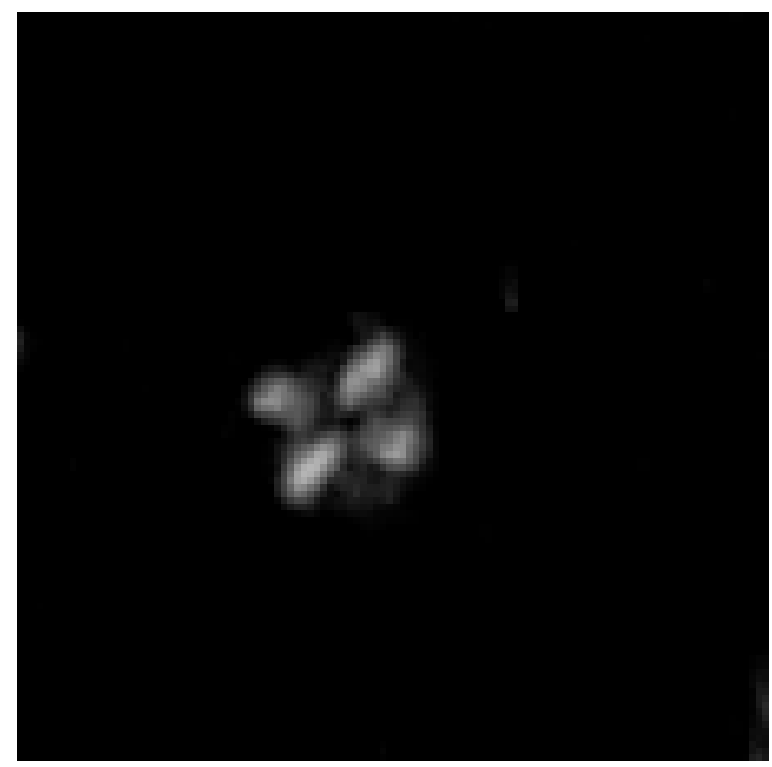

Plate 4. Micula decussata [21]. 


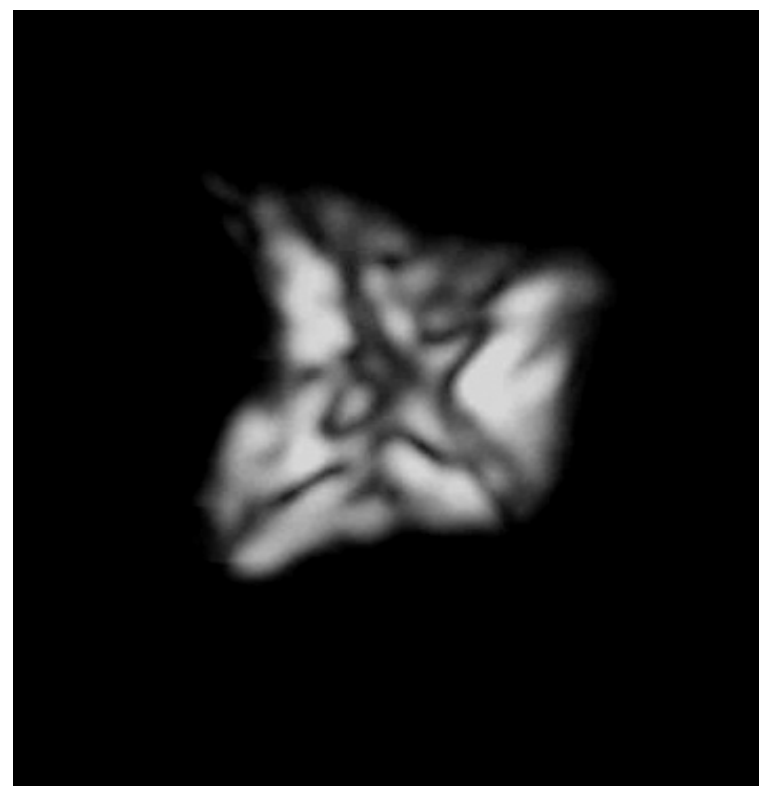

Plate 5. Icula concava [23].

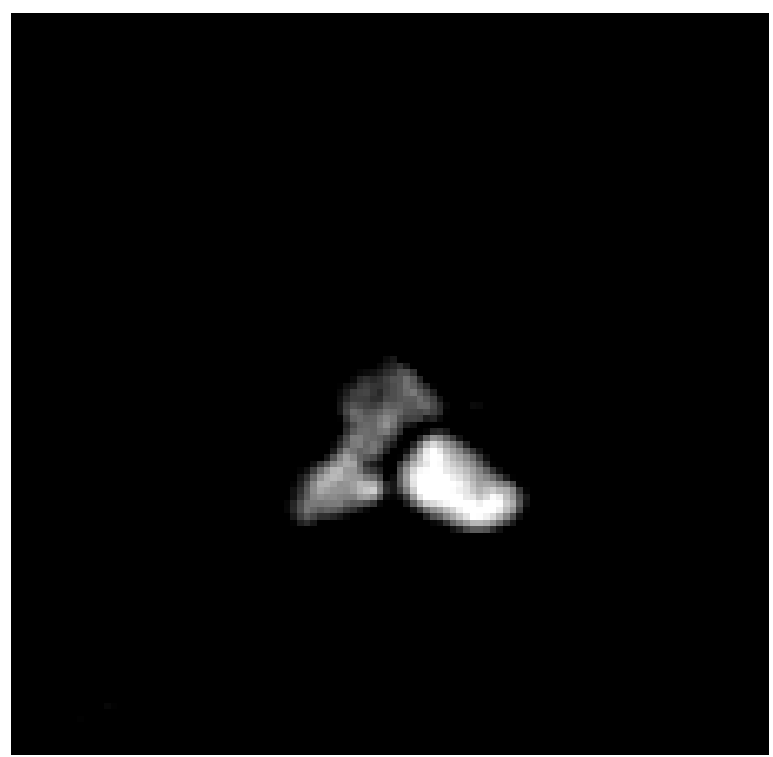

Plate 6. Uniplanarius trifidus [24].

other two arms. Age range is the end of late Campanian.

Plate 7: This is a Coccolith that is known by one radius cycle consists of four long and specified radius. End of the branches is sharp and the central region is very regular. This species is used as indicators of zoning CC21 [26]. The first appearance of this species is in CC21 zone that appears at the end of Late Campanian age.

Its age range is the beginning of late Campanian.

Plate 8: This type of Coccolith is round to elliptical shape with a stem. Its central region is wider than other species and its central cross is ${ }^{*}$ shape. Its age range is Campanian-Maastrichtian. 


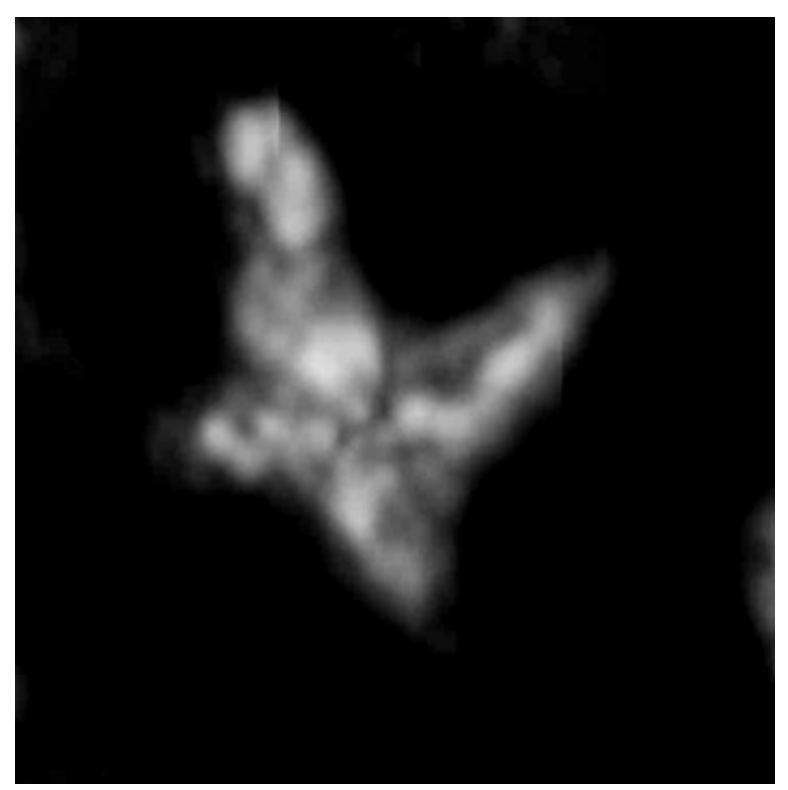

Plate 7. Uniplanarius sissinghii [25].

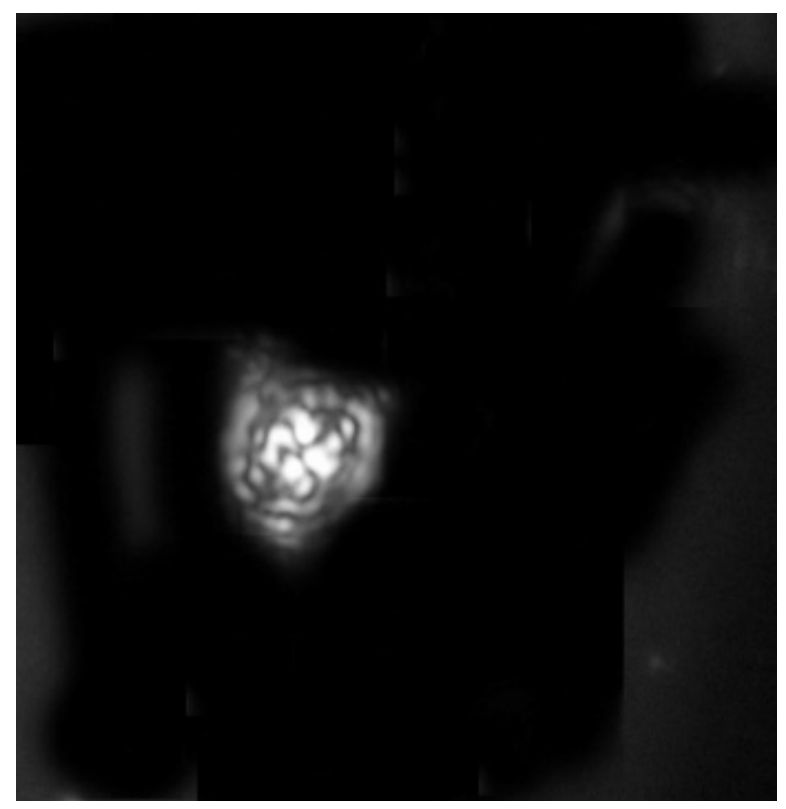

Plate 8. Prediscosphaera cretacea [27].

Plate 9: This type is known by having two arms and a head, which are well developed. Earlier forms have 4 short arms and one long head and other forms have two longer arms and a shorter head, respectively. On the other hand, earlier forms $C$. aculeus can be distinguished from $C$. verbeekii by three arms, which are seen in normalpolarized light in $C$. verbeekii. However, in $C$. aculeus, two arms can be seen just in ordinary and polarized light, and the angle between the two arms in this type is more than 90 degrees during the Campanian and in Maastrichtian is less than 90-degrees. The age range of it is beginning Campanian-late Maastrichtian. 


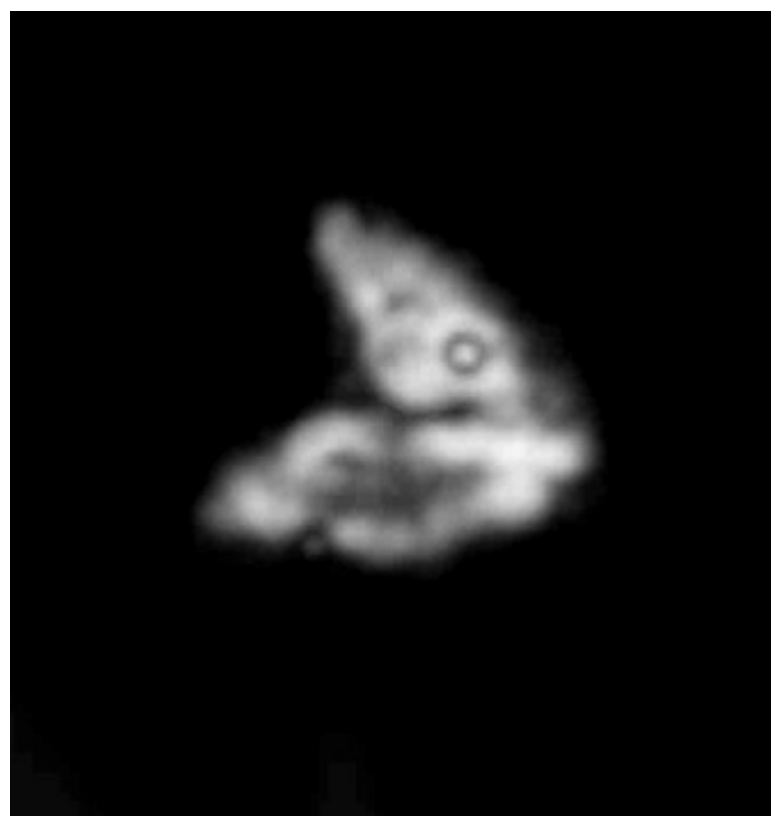

Plate 9. Ceratolithuides aculeus [28].

\subsection{Biozonation of Kopet Dagh Basin}

Calcareous Nannofossil is heterogeneities and a very diverse group, from the remains of calcareous plankton and includes, Coccolithophores and affiliated groups, which are the same in terms of size and chemical composition, but their relation to each other is not clear too much. So far, comprehensivestudies of biostratigraphy have been done in this basin on calcareous Nannoplankton of Cretaceous onSarcheshmeh, Aitamir, Abderaz, Abtalkh, Neyzar and Kalat have been made. Aitamir lower part formation in the cutting of Shurab [29] were studied based on calcareous Nannoplankton and the age of formation at the bottom of this section, the biozones equivalent of CC11-CC12, and considering Stratigraphy biozones introduced, the late Cenomanian-early Turonian age was proposed for this part of Aitamir formation. The upper section of Aitamir in the cut of Shurab [27] was studied and biozones Aitamir formation of CC12, CC16, CC17 was proposed andbased on stratigraphic biozones value, the section of study age is late Turonian-Late Santonian/beginning Campanian. AbDeraz Formation was studied for the first timebased on Nannofossil in type section [30] and cutting of Taherabad [31].

\section{Conclusion}

According to studies carried out on calcareous Nannofossil, the bottom part of Abtalkh formation sediment, the study section, the following results have been achieved from different viewpoints: During this study, for the lower part of Abtalkh formation in Aitamir cutting, a total of 9 genera were identified. Recognized calcareous nannofossils have diversity and abundance, relatively good. According to biostratigraphic, given the emergence and extinction of index species and fossil assemblages, 4 biozones were identified for the studied shear in accordance with zones (CC18-CC21) of Sysyngzon- 
ing, 1977. Based on the defined stratigraphic biozones value, the deposition time of the bottom Abtalkh formation is recommended the beginning Campanian to the Late Campanian.

\section{References}

[1] Agha Nabati, A. (2004) Iran's Geology, Geological Survey of Iran, Tehran, 586 p.

[2] Khosrow Tehrani, Kh. (1988) General Information about Iran Stratigraphy and Sections Brigades. Tehran University Press.

[3] Darvishzadeh, A. (1991) Geology of Iran. Dissemination of Knowledge Today (Amir Kabir Publishing Institute).

[4] Sanaati, A. (1998) Ab Deraz Formation Biostratigraphy Based on Calcareous Nannoplankton. The Senior Thesis, Ferdowsi University of Mashhad.

[5] Moteie, H. (2003) Iran's Geology (Geology of the Zagros). Geological Survey of Iran, 84.

[6] Hadavi, F. (2001) Nannofossils Abtalkh Fomation in the West Village of Chehchehe. The Twentieth Meeting of Earth Sciences.

[7] Hadavi, F., Pooresmaeel, A. and Notghi Moghadam, M. (2008) Calcareous Nannoplankton. Mashhad Ferdowsi University Press.

[8] Arkhangelsky, A.D. (1912) Upper Cretaceous Deposite of East European Russia. Materialian zur Geologie Russlands, 25, 1-631.

[9] Berberian, M. and King, G.C.P. (1981) Towards a Paleogeographic and Tectonic Evolution of Iran. Canada Journal of Earth Science, 18, 210-265. https://doi.org/10.1139/e81-019

[10] Bown, P.R. (1993) New Holococcoliths from the Toarcian-Aalenian (Jurassic) of Northern Germany. Senckenbergiana Lethaea, 73, 407-419.

[11] Braarud, T. and Nordli, E. (1952) Coccoliths of Coccolithus huxleyi Seen in an Electron Microscope. Nature, 170, 361-362. https://doi.org/10.1038/170361a0

[12] Bralower, T.J. (1987) Valanginian to Aptian Calcareous Nannofossils Stratigraphy and Correlation with the Upper M-Sequens Manetic Anomalies. Marine Micropaleontology, 11, 293-310. https://doi.org/10.1016/0377-8398(87)90003-X

[13] Bramlette, M.N. and Riedel, W.R. (1954) Stratigraphic Value of Discoasters and Some Other Microfossils Related to Recent Coccolithophore. Journal of Paleontology, 28, 385-403.

[14] Bronnimann, P. (1965) Microfossils Incertae Sedis from the Upper Jurassic and Lower Cretaceous of Cuba. Micropaleontology, 1, 28-51. https://doi.org/10.2307/1484409

[15] Bukry, D. (1969) Upper Cretaceous Coccoliths from Texas and Europe. The University of Kansas Paleontological Contributions, Article 51 (Protista 2), 1-79.

[16] Bukry, D. and Bramlette, M.N. (1970) Coccolith Age Determination Leg 3, Deep Sea Drilling Project. DSDP Initial Reports-Deep Sea Drilling Project Reports, 3, 589-611. https://doi.org/10.2973/dsdp.proc.3.118.1970

[17] Bukry, D. (1973) Coccolith Stratigraphy Eastern Equatorial Pacific. 611-653.

[18] Burnett, J.A. (1998) Upper Cretaceous. In: Bown, P.R., Ed., Calcareous Nannofossils Biostratigraphy, Chapman \& Hall, London, 132-199.

[19] Cepek, P. and Hay, W.W. (1970) Zonation of the Upper Cretaceous Using Calcareous Nannoplankton. Palaobotanik, 3, 333-400.

[20] Crux, J.A. and Heck, S.E. (1987) Nannofossils and Their Applications. Proceedings of the International Nannofossil Association Conference, London, 356. 
[21] Dercourt, J., et al. (1986) Geological Evolution of the Tethys Belt from the Atlantic to the Pamirs since the Lias. Tectonophysics, 123, 241-315. https://doi.org/10.1016/0040-1951(86)90199-X

[22] Ehrenberg, C.G. (1836) Bemerkungen uber feste mikroscopische anorganische Formen in den erdigen und derben mineralien. Bericht. Verh. K. Preuss. Akad. Wiss, Berlin, 84-85.

[23] Erba, E. (2004) Calcareous Nannofossils and Mesozoic Oceanic Anoxic Events. Marine Micropaleontology, 52, 85-106. https://doi.org/10.1016/j.marmicro.2004.04.007

[24] Hadavi, F. and Khodadadi, L. (2002) Calcareous Nannoplankton of the Campanian-Maastrichtian of NE Iran. Journal of Nannoplankton Research, 24, 109.

[25] Hadavi, F. (2004) Calcareous Nannofossils from the Abtalkh Formation (CampanianMaastrichtian), Kopet-Dogh Range, NE Iran. Journal of Nannoplankton Research, 26, 6368.

[26] Haq, B. (Ed.) (1983) Nannofossil Biostratigraphy, Benchmark Papers in Geology. Hutchinson and Ross, Stroudsberg, 79.

[27] Van Heck, S. (1979) Nannoplankton Contents of the Type-Maastrichtian. INA Newsletter, 1, N5-N6.

[28] Huber, B.T., Hodell, D.A. and Hamilton, C.P. (1995) Middle-Late Cretaceous Climate of the Southern High Latitudes: Stable Isotopic Evidence for Minimal Equator-Pole Thermal Gradients. Geological Society of America Bulletin, 107, 1164-1191. https://doi.org/10.1130/0016-7606(1995)107<1164:MLCCOT>2.3.CO;2

[29] Huxley, T. H. (1868) On Some Organism Living at Great Depths in the North Atlantic Ocean. Quarterly Journal of Microscopical Science, 8, 203-212.

[30] Inouye, I. and Kawachi, M. (1994) The Haptonema. In: Green, J.C. and Leadbeater, B.S.C., Eds., The Haptophyte Algae, The Systematics Association Special Volume No. 51, Clrendon Press, Oxford, 73-89.

[31] Jafar, A.S. (1983) Significance of Late Triassic Calcareous Nannoplankton from Austria and Southern Germany. Neues jahrbuch fur Geologie und Palaontologie-Abhandlungen, 166, 218-259.

\section{Submit or recommend next manuscript to SCIRP and we will provide best service for you:}

Accepting pre-submission inquiries through Email, Facebook, LinkedIn, Twitter, etc. A wide selection of journals (inclusive of 9 subjects, more than 200 journals)

Providing 24-hour high-quality service

User-friendly online submission system

Fair and swift peer-review system

Efficient typesetting and proofreading procedure

Display of the result of downloads and visits, as well as the number of cited articles

Maximum dissemination of your research work

Submit your manuscript at: http://papersubmission.scirp.org/

Or contact ojg@scirp.org 